\title{
Agricultural Hybridity and the "Pathology" of Traditional Ways The Translation of Desire and Need in Postcolonial Development
}

By

Chris J. Shepherd

GLOBALISM INSTITUTE, RMIT UNIVERSITY, MELBOURNE

\section{R E S U M E N}

Este trabajo conecta el análisis de traducción en la Téoria de Red de Actores de la Sociología de la Ciencia con la Antropología del Desarrollo, a fin de considerar el proceso por el cual los proyectos de desarrollo efectúan cambios en el conocimiento y la práctica de la agricultura andina. El enfoque de la traducción es en los deseos y necesidades de los campesinos andinos cuando estos se comprometen con organizaciones de desarrollo agrícola no gubernamentales que tratan de difundir las tecnologías de la agricultura científica. Recurriendo a datos etnográficos obtenidos en los Andes del sur del Perú, este trabajo sigue las construcciones del deseo y la necesidad que hacen el desarrollo tan plausible cuanto problemático, dadas las diferencias entre el saber del personal de proyectos de desarrollo y el saber local. Se concluye que en los casos en que estas diferencias convergen en nuevos amalgamas de conocimiento del desarrollo y prácticas locales, los híbridos emergentes deben ser tanto historicizados como politizados, en vez de ser simplemente interpretados como mezclas sincrónicas de prácticas culturales.

PALABRAS CLAVES: desarrollo agrícola, organizaciones no gubernamentales, saber local, hibridismo, Teoría de Red de Actores. KEYwords: agricultural development, non-governmental organizations, local knowledge, hybridity, actor-network theory.

$\mathcal{B}$

ORN AND TRAINED IN LIMA, Victor is a veterinary scientist who now works with a non-governmental agricultural development organization in the vicinity of Cusco in the southern Peruvian Andes. ${ }^{1}$ Over the past few months, he has been visiting a

The Journal of Latin American Anthropology 9(2):235-266, copyright (C) 2004, American Anthropological Association 
community — Llactapata — as part of a project to supply the local people with new livestock management methods aimed at increasing meat production for market sales. The project, however, is not running smoothly for, according to Victor, the community has been "behaving irrationally": the community members' interest in the project seems fickle and they keep disappearing when they are needed. Having "unnecessarily" prolonged the construction of special feeding troughs and other infrastructure, the peasants now find themselves confronted by an exasperated Victor who urges them to make up their minds once and for all whether they are going to participate in the project or not. Addressing one peasant, Victor implores, Piensa bien lo que te conviene hacer-ison cosas productivas! ("Really think about what you need to do-it's a matter of productivity"). The peasants of Llactapata renew assertions to the effect that they are enthusiastic and will continue building the infrastructure and attend a forthcoming training course. Victor, however, remains skeptical, and as he leaves the development site he shakes his head and confides to me, the visiting researcher, that these "traditional ones" "son enfermos—casos para el sicólogo" (They're sick—cases for a psychologist).

Indeed, besides anthropologists and sociologists, psychologists too have been brought into the fray of development to assist that "regime" of technical expertscalled promotores - through whose relentless yet many times frustrated efforts the development of the "impoverished others" is pursued. Yet if we, as scholars of anthropology and postcolonial science, are to remain agnostic on the "mental health" of development's ambivalent subjects, how can we better understand their desires, their needs and their-by now much celebrated—resistance"? ${ }^{2}$ I answer this question by proposing that development organizations actively go about the task of shaping the desires of subjects. They do so by encouraging "beneficiary subjects" to understand their needs in the way the development industry construes community needs with the expectation that subjects begin to act in the world in the way held for them. In other words, promotores such as Victor seek to affiliate the development agenda with the desires of "underdeveloped" community members by both explaining the benefits of new knowledge and technology and by informing them on their "real" needs.

Promotores are also subjects of development. Historically shaped, funded and regulated by international agencies on an ongoing basis, they too are immersed in the world of development and constituted by its discourses and practices. Positioned on the "other side", the side of the activists, they are qualified as bearers of expertise. They need to appear unambiguously committed to their task while, in contrast, development's subjects at the receiving end are measured and judged according to how responsive they are to programs and initiatives, impressing the promotores for their "dynamism" and "progressiveness." If they fail to do so, they become development's "slackers" whereby they receive their pejorative designations 
as "lazy", "irrational" and "traditional" among many others.

Development as it is practiced in comunidades campesinas of the southern Andes bears this out. A dualism is institutionalized between promotores and campesinos with cognitive authority vested in the former. With knowledge relations historically institutionalized in such a manner, promotores proceed to cement campesinos' cooperation and willing participation in projects that in many cases promote far-reaching changes in productive modalities, social organization, and knowledge. As I argue in this essay, this does not arise spontaneously but rather entails the construction of the very states or dispositions conducive to such changes. In short, development aims to create the social environment in which it can further generate and extend itself into the life world of its subjects, both promotores and campesinos. How this is produced and how the power relations that drive this process are established are the main focus of this essay.

I illustrate the argument by drawing on ethnographic data collected in the southern Peruvian Andes in 1997 and 1998 as I followed the routine activities of agricultural development non-governmental organizations (NGOs) in their ongoing interactions with the indigenous campesinos. These campesinos were comuneros (community members) residing in agropastoral communities that had long been impressed by all manner of development initiatives by the state and, increasingly, by the NGOs that now peppered the institutional landscape. The research was concerned with the relationship between knowledge and power as development's promotores encountered these campesinos of comunero status. ${ }^{3}$ In particular, as participant observer within three NGOs in Cusco, I was interested to find out how the participation of campesinos was negotiated and the way negotiations were mediated through differential power relations between promotores who were "experts" in the applied agricultural sciences and campesinos who were seen to be "non-expert" farmers supported by, as it were, "traditional technologies." Within this power dynamic, the focus of research was on the types of strategies that developed, both formally and spontaneously, to encourage the uptake of new technologies and new farming practices. Given that campesinos were not coerced to participate, it became clear that in order to be effective, promotores had to direct the emotional and behavioural responses of campesinos towards development's innovations to ensure a satisfactory level of cooperation; part of this depended upon the deployment of strategies which, in effect, persuaded campesinos to desire particular outcomes. The "desirability" of these outcomes, however, was not selfevident since they did not automatically see the world in the way promotores had been trained to see it for them. As such, desire had to be translated by redefining for campesinos the very world in which they lived.

These translation processes form the ethnographic bone of this essay. My interpretation relates the constructed roles of expertise and non-expertise in farming 
regimes to our understanding of cultural hybridity and the dialectic relationship between local knowledge and external knowledge, Andean knowledge and Western knowledge. The validity of boundaries drawn between knowledge systems and disparate ontologies remains a much-debated question, which has become more rather than less complicated as notions of hybridity and hybridization have entered anthropological and postcolonial lexicons. Rather than posit fixed realms of what comprises Andean and Western knowledge, I suggest that at any given time in a given community, a certain knowledge configuration will exist while "other knowledge" will be considered external and unfamiliar. Tracing the essentially uneven influence of "modernity-as-development-and-progress" (Yúdice, 1992:4) in the Andes is, among other things, about following the social processes, knowledge relations, and power dynamics, which turn the external into the internal. As this movement occurs across divides in class and ethnicity, an inevitable transformation occurs-a hybridization of forms, meanings and practices- that gives rise to hybrids that are rearticulated in "development's culture" as much as in "traditional culture" (See Yúdice, 1992).

To pursue this line of interpretation, I deploy translation analysis of the Actornetwork Theory to tease out what I call "diachronic hybridity." I link translation and hybridity to constructs of traditional and modern knowledge and to the pathologization of "others." The latter remains a salient feature of development's interface with indigenous Andeans. I suggest that our very notion of hybridity needs to become more hybrid, emphasizing both the atemporal (synchronic) and temporal (diachronic) aspects of hybridity as a postcolonial process "in the making." Accordingly, we can advance our understanding of modernity in the Andes through the dynamics of "enrolment" - the building of convergent interests—as multiple actors of diverse vocational, social, and ethnic positions are immersed within the tensions of development.

\section{Synchronic hybridity and translation}

Suggesting the mixings and appropriations of and between culture, race, identity, knowledge, practice, discourse, materials and geographies, hybrids, as Robert Young observes, may be conceptualized as either, firstly, a kind of intermingling of "originals" in the creation of something new or, secondly, a continual mixing of mixes whose "origins" are an abstract, lost or inconsequential aside to the "permanent revolution of forms" (1995:22-26). ${ }^{4}$ If in general the anthropology of development has cautiously acknowledged the first conceptualization, thereby framing hybridity as a form of cultural borrowing and incorporation (Andeanization) and returning to a more or less integral, albeit dynamic, notion of culture (Ploeg, 1993; Apffel-Marglin, 
1994, 1998, Gelles, 2000), recent constructs of hybridity-influenced particularly by the interdisciplinary cultural studies movement-have embraced the amorphous recombinations indicative of the second conceptualization. The latter is associated with an ethnographic style which I call "synchronic hybridity": a mode of describing particular hybrid forms that are manifest in a postcolonial present but which are analytically separable from historical and political content or specification and depend overwhelmingly on "observed traits" rather than "lived experience."5

To illustrate synchronic hybridity in a postcolonial and ethnographic context (one which in many ways is similar to the one of this paper ${ }^{6}$ ), I draw on Akhil Gupta's Postcolonial Developments (1998). This study of a region in northern postindependence India invokes a "postcolonial condition" inhabited by, inter alia, hybrids constituted simultaneously by local understandings of agriculture and globally and nationally circulating discourses of development. Citing the example of Alipur villagers who readily accept their locations as "underdeveloped" and "backward," he argues that such declarations are best seen not as external impositions but as constitutive of local lives and local systems of meaning in rural north India. In attempting to dissolve the distinction between that which is local and that which is external, he not only places these terms inquotation marks, he also goes on to ask: "Was there, then, any good reason to regard discourses of development as 'external' and indigenous knowledges of agronomy as 'internal' to the lives of the people of Alipur?" (1998:6)

Gupta is correct in his assessment that external discourses and objects come to constitute the local in a peculiar and necessarily hybridized form. This "statement of fact" provides the first thematic impetus for this essay-it holds true for modernity in the Andes as much as it does for India. Modernity in this sense is less an encroachment or imposition than it is a form "already there" mixed up in Andean ritual, language, agriculture or any thing we care to look at. The second thematic impetus of this essay departs from Gupta's analysis by looking at any hybrid outcome as a temporary apparition. If Gupta is able to look back upon the Green Revolution in India suggesting that theory which posits different cultural systems "fails to account for the enthusiasm with which farmers took up green revolution agriculture" (1998:6, emphasis added), I maintain that enthusiasm-or what in this paper I call "desire" - is negotiated and reconstructed through cultural difference. At least in the Andean context, differences in knowledge, expertise, productive strategies, and ethnic relations underpin the diachronic character of hybridization processes which come to settle in what may be observed at any historical juncture as a synchronic hybrid. ${ }^{7}$

With the focus placed squarely on differences between internal and external knowledge in the Andes, the desire to "adopt" new agricultural practices is ance an interpretation, a process, and lastly, but not necessarily, an embodied feeling. The 
desire of campesinos is persistently appropriated by development itself: campesino desire is spoken for by promotores and their lack of desire is accounted for, problematized, and used to support any number of stereotypical pathologies of "traditional" ways. Moreover, the desire of campesinos, in the form of their cooperation, often takes years to establish and yet, even so, remains contingent. It is too simple, therefore, to look at a development context at a given historical point and tell a story of an unconditional enthusiasm for the products of the Green Revolution, "modernization" or agricultural development in general. This is to misunderstand how development works. Desire itself is in myriad ways socially negotiated on uneven terrain. It is subject to power and knowledge relations that are at once embedded in discourses and filtered through the structures of class, race and gender as development projects run their course. ${ }^{8}$ Moreover, desire co-constitutes the processes of change that come to define and redefine what is to count as internal and external knowledge at any given moment in a given place. Definitions and meanings, of course, do not spring from nowhere. They are the results of translation.

What, then, is meant by translation? Briefly, the notion of translation I deploy here derives from the French Actor-Network Theory developed by Bruno Latour and Michel Callon (Callon, 1986; Latour, 1987, 1993). Providing a relativist sociological explanation for the construction of scientific knowledge, the theory of translation holds that objects, material and discursive, do not exist in and of themselves in any pre-social or natural form. ${ }^{9}$ Rather, the symbolic/material meanings of objects are emergent: they are socially negotiated, contested and/or (de)legitimized within and between groups of unequal position, power, and resources, and thus they become (or fail to become) translated into a network of more or less stable social and material relations. In short, they constitute a sociotechnical assemblage. ${ }^{10}$ Emphasizing the assemblages of heterogeneous bits and pieces that comprise a network, actors translate objects incorporating them into their network. As this incorporation ensues through space and time, the very meaning and substance of those objects is transformed to suit the new "idiom"; hence "translation" which proceeds apace transforming social arenas and the world of objects while the newly constituted objects also translate the world into which they move. ${ }^{11}$ Besides translation, Latour (1993) also draws attention to a parallel practice: that of purification which is similar to reification or naturalization in other contexts, and is a strategy which functions to conceal the whole gamut of translations, firstly, by reproducing the divide between the "Natural" and the "Social" worlds and, secondly, by pushing those translations into the category of the "Natural." In the process, those translations come to be seen as "facts" or "natural" objects (Latour, 1987).

But this is far more specific than the idea that the properties of objects are socially negotiated. Rather, objects are fashioned to cater to the interests of others, such that through the emergent properties of objects alliances are forged and 
secured, thereby "enrolling" others in a network that simultaneously confirms its own reality (Latour, 1987:108-11). In the context of this paper, this means that promotores must devise ways of cojoining their interests with those of their subject campesinos, just as distant donor agencies have to link their interests to those of promotores. In order to successfully enroll the interests of others and ensure the collaboration of campesinos, translation and purification strategies are critical insofar as they aim to establish the desirability of particular knowledge, agricultural practices, and outcomes.

The three NGOs dealt with (but not identified) in this essay had their head offices in Cusco and brought their projects to rural peasant communities in the northern and north-eastern provinces of Urubamba, Calca, and Paucartambo. The NGOs employed between 30 and 100 people, approximately half of whom either held university degrees in biological, agricultural or veterinary science, or had some technical training in these fields. Staff was drawn predominantly from the local Cusquean mestizo population, though some, in particular the directors and the more highly qualified, originated from coastal Peru. Only a few NGO workers were of the rural campesino class, who were either employed in a menial capacity or, if employed in a technical capacity, no longer self-identified (or could be identified) as campesino. Thus people of diverse backgrounds came to share the identity of NGO "promotor". This identity was necessarily a synthesis of development discourse and its existence in differential social and topographic locations within Peru. Specifically, the class- and race-based beliefs that distinguish coastal Peruvians from highlanders; urban nobility and mestizos from rural campesinos; Spanish speakers from Quechua speakers etcetera, also imbued the identity of promotor and ideas about what development work meant. For promotores, then, development and underdevelopment offered new ways of articulating cultural and ethnic differences and similarities while operating within the highly legitimate cultural sphere of development work and scientific and agricultural extension in an area multiply constituted as underdeveloped. ${ }^{12}$ Within a given development organization, the tensions of hierarchy and social status, although evident, were diffused by the common vocational identity, whereas between promotores and campesino subjects, those differences were often magnified.

Yet the very hybrid character of development's place in Peruvian society was obscured by development's discourse itself for it all seemed to be about projects, production, and socioeconomic betterment for the impoverished. The development initiatives operationalized within a total of some eighty communities were diverse, ranging from irrigation, seed, and livestock projects to community organization and technical training and marketing workshops. In all instances, expert knowledge in agronomy, applied biology, animal husbandry, conservation science (including agroecology), and agricultural economics, among others, formed the 
backbone of these projects and contributed, alongside the rhetoric of sustainability and gender, to the "official voice" of the NGOs. In order to justify these interventions, all three NGOs looked upon existing farming practices as inefficient in technology and resource use, and they construed the social organization and economic/commercial skills of peasant communities to be deficient.

The three NGOs among which my research was carried out constitute part of the wide diversity of NGOs throughout Latin America. Yet as a sub-group of agricultural development NGOs, they share a common history as what I call "second generation" development NGOs. ${ }^{13}$ This new generation of development NGOs emerged in the 1980 os and was less radical and politically engaged than their "first generation" predecessors. Those whose endeavors were directed toward the development of agriculture in the Peruvian Andes in particular, sprung up as urban, mainly coastal, Peruvians responded to the availability of international funding at a time when multilateral organizations sought to circumvent the state apparatus to bring the benefits of the Green Revolution (GR) to "small-holders" previously excluded by its capital intensive and large-scale orientation (Escobar, 1995a). Notwithstanding the community focus of these development NGOs that addressed the agriculture of campesinos in particular, they largely shared the abiding assumption of Integrated Rural Development, which consisted in asserting that for campesinos to develop they must integrate into the national economy (Mayer and Glave, 1992:87-8) in such a way that the backward agricultural sector of the highlands could bolster rather than hinder the most dynamic, coastal, sectors and thereby expedite industrialization (Plaza, 1990). This indeed explains why agricultural NGOs of this type developed strong links with Peru's National Agricultural Research Stations as well as with Lima's International Potato Center (CIP), one of many International Agricultural Research Centers (IARC) now scattered throughout the world. It is this body of national and international research institutions whose agenda was established by North American interests in the postwar period that set the technocratic drive for Andean agricultural development (Bebbington and Thiele, 1993; Jennings, 1988; Shepherd, forthcoming). After the Agrarian Reform of 1969 and subsequent experiments in cooperatives and enterprises, the technical thrust had come into its own by the 1980s, effectively subsuming social and civic discourses to technical ones. While this was most apparent in state-led development initiatives such as those described by Gelles (2000), it also held for most NGOs that emerged in the early 1980 os notwithstanding their professed interest for the perspectives of the social sciences (see Bebbington and Thiele, 1993).

While the GR has gradually given way to a more diversified set of developmentalist discourses and practices, its technocratic and market approach continues to guide NGO interventions today and many community projects still bear the insignia of the GR style with an emphasis on greater productivity through high- 
yielding seed and hybrid animals, chemical inputs and irrigation technology. COINCIDE (Coordinación Intercentros de Investigación, Desarrollo y Educación) an umbrella organization for NGOs in Cusco, sums up the position for the majority of agricultural development NGOs at the height of neoliberalism.

Plantearse hoy la promoción del desarrollo en el medio rural andino requiere pensar en la integración de la economía campesina al mercado. Es allí donde se definen los precios y donde necesitamos generar condiciones para lograr una mejor retribución por el trabajo productivo. Consideramos imprescindible incursionar en la esfera de la comercialización para complementar los programas de desarrollo que realizamos en el sector rural, los cuales han estado centrados, fundamentalmente, en la introducción de cambios tecnológicos para aumentar la producción y productividad como medio para mejorar los ingresos y la calidad de vida de la población (Domingo, 1995:7). ${ }^{14}$

The "market" however, is certainly not the invention of development. For centuries, Andean Indians were active in redirecting agricultural and other mercantilist activities toward commercial ends while resisting the worst forms of market control (Larson, 1995). But by the early century, a combination of liberal reforms in land and tax, nation-building ideologies, and the dominance of mestizos converged to severely stifle the freedoms and adaptive strategies available to Indians (Harris, 1995). It was only in the latter half of the twentieth century, and particularly following the Agrarian Reform of 1969 and the legislated identity shift from "Indian" to "campesino," that peasants were able to reinvigorate market involvement to compliment their collective strategies of agropastoral subsistence. Yet the terms of this reinvigoration were largely taking shape within the confines of national and global development priorities, determining both the technological direction of innovation and the highly inequitable terms of exchange that campesinos were being drawn into (Escobar, 1995a; Mayer and Glave, 1992). Under such conditions, it is not surprising that in the Andes, as elsewhere, we find social groups struggling not only to control resources but also struggling to culturally define and organize those resources (Gelles, 2000:3).

It is within this complex socio-cultural landscape that agricultural development NGOs began to assert their authority. The particular NGOs with which I carried out fieldwork embodied the orthodox position on agricultural development, although they distinguished themselves adamantly from the ways and means of state officialdom. For their part, the eighty or so Quechua communities of Urubamba, Calca, and Paucartambo visited by this group of NGOs, lived and farmed on communal lands at elevations of between 2000 and 4000 meters. Consisting of between 20 and 50 families, the communities cultivated potatoes, maize, quinoa, wheat, barley, 
beans, and vegetables; some herded cattle, sheep,and less frequently, alpacas. Although largely subsistence farmers who sometimes sought seasonal employment outside the communities, these campesinos had increasingly come to sell surplus produce at local markets or in Cusco. But despite the persistence of promotores in encouraging campesinos to focus on market-oriented production, campesinos manifested a strong allegiance to their own agricultural and pastoral modalities that constitute their "ethnic economy." 15 As Olivia Harris (1995: 372) argues, it is "the enduring strength of community organization [that] sets limits on the full mercantilization of the rural economy."

\section{Desire, Need and Resistance}

We may begin by looking at the way in which development insists on purifying desire through constructs of "need." One of the basic tropes of development is that its "beneficiaries" - the impoverished, the underdeveloped — need development: hence they are the "needy." 16 In the face of an endless articulation of "their needs" by the conglomerate of Western development institutions, it is readily assumed that they, development's subjects, also want development. Yet if we move further into the social spaces where projects are implemented by development organizations and received by those considered to be the "most needy," namely rural, indigenous peasants of the "marginal lands" of the Andes, we encounter a curious addition to the discourse: the poor, of course, continue to need development according to those local authorities who speak on their behalf, but the matter of whether they want development is no longer assumed to be true. ${ }^{17}$

Instead, a paradox arises: it is reiterated both that quieren desarrollarse (they want to develop) and no quieren desarrollarse (they don't want to develop). The enunciative context of these contradictory terms is complex and ambivalent. "They want to develop" arises not because this is "a matter of fact," but rather because within rural development organizations there is often a good deal of uncertainty and confusion as to what peasants do want, their wants being measured by their degree of cooperation with the organizations as the latter concoct plans and projects "for them." Given the variable and stringent conditions of external funding, agricultural development NGOs in particular typically manifest anxiety about whether projects are going to succeed or fail, and in the face of subjects whose cooperation and reliability appear fickle, ambiguous, or non-existent, promotores are wont to reassure themselves, donors, assessors, and visiting researchers alike, that development really is desirable. ${ }^{18}$ That "peasants want to develop" is a powerful vindication of development's interventions which are susceptible to all manner of contingencies (including the often pronounced ambivalence of subjects toward 
projects) which, in sum, seal the fate, successful or not, of development projects and, ultimately, the agencies who run them. ${ }^{19}$ It is at those frustrated moments when NGO projects go awry or go nowhere, that one is likely to hear "they don't want to develop."

Faced with ambivalent subjects, NGOs work hard to ensure that a measure of convergence between desire and need is attained and sustained over time. Promotores assume the role of encouraging "beneficiaries" to appreciate the logic of development projects and become willing and "rational" participants. That the peoples targeted by development "want to develop" is the idealized counterpart of the prescriptive "you should want to develop" and the mandate to peasants "cooperate for your own good" within a context of insecurity where divergence is as common as it is difficult to comprehend. Divergence is equal to the inevitable and ongoing tensions between need and desire, and in practice it is commonly understood through the simple and categorical notion of "resistance."

In discourse analyses of development (Crush, 1995; Escobar, 1984, 1995a; Sachs, 1992) — or what has elsewhere been called the "development dictionary perspective" and associated with "Post-development"20_a dominance/resistance model has been generalized at the expense of accounting for local situations and peculiarities (Pigg, 1997). Resistance to development is rather a locally generated interpretation emerging within particular contexts and does not necessarily reflect a pan-Andean, nor a generalized or organized postcolonial, opposition to development in general. ${ }^{21}$ As such, resistance needs to be treated as a locally produced effect within a matrix of complex social relations, not only between promotores and campesinos but also between these and their broader environments, of which development organizations are but one aspect.

Yet at least for the sake of donors (if not for themselves too), NGOs tend to simplify campesinos' livelihoods and options, while presenting themselves as saviors of sorts to the scourge of underdevelopment and poverty. Following donor guidelines and requisites, NGOs design projects for the campesinos and campesino communities. Although simplified descriptions and assessments of any given project are presented to donors, strategically mimicking the discourse of development and the particular policies of the donor agencies, the application of interventions is far more complicated, messy and contingent than NGOs would have donors believe, and many factors combine to frustrate the operation of projects. As I outline below, both the agency of campesinos and the complex socioeconomic and intercultural relations in the Andes combine to make it impossible for promotores to simply treat the technical aspects of agricultural production independently. What follows are some of my observations of the difficulties promotores faced in their routine interactions with campesinos.

Relative to promotores who actively engaged campesinos to urge them to take 
up new agricultural methods, campesinos came to appear as slackers. A perceived lack of interest toward NGO initiatives was commonplace, expressed through campesinos' absence when they were expected either to attend a given activity (such as a training workshop at the NGO office) or to be available for discussion, instruction or to receive materials when promotores visited their communities. It is important to consider that when promotores made such arrangements, these appointments were noted in the NGO's programación (formal institutional schedule). The campesinos, for their part, were evidently not committed to any programación. For them there was no such thing and they acted, presumably, according to how they saw fit at the time, in their own time and according to their own precepts of what they would do in their time. They did not, therefore, automatically abide by the schedules of outside organizations. While promotores generally interpreted this kind of "behavior" as "resistance,"there was no evidence that this apparent "slacking" was motivated by a direct desire to undermine the initiatives of promotores. ${ }^{22}$

In contrast, campesinos sometimes negotiated to seek advantage from NGOs. From the stories that circulated among NGOs it was possible to gain insight into how peasants "misconstrued" the rules of the "development game." On one occasion, the Director of an NGO compared worthy with unworthy campesinos in relation to the proper distribution of credit:

Hay campesinos excelentes a quienes vamos a dar unos dos mil dólares. Pero hay los que piden una suma astronómica, y les preguntas para qué es, y no te saben contestar. Los campesinos se dicen los unos a los otros, pide nomás, pide nomás. ${ }^{23}$

There were campesinos, then, who had learned how to "be excellent" and how to gain from credit institutions. And yet there were those "naïve" ones who had not grasped this, and they told each other pide nomás ("just go and ask, nothing more"). In development's terms they were naive; in their own terms they were simply requesting the benefits which, they might have assumed, were freely available from resource-rich organizations. Illustratively, the same director proceeded to speak of campesinos who, by all accounts, might be seen to be clever and determined yet, ultimately, self-defeating:

Hay gallinas que comen sus propios huevos aunque se les corten el pico.. los que tienen una capacidad bárbara de sumar información, y van de una institución a otra para sacar dinero, y montan todos los recursos para hacerlo ... el crédito no es para ellos. $^{24}$

These campesinos excluded themselves from the rewards they had astutely found out how to receive. Here the Director was generating a moral economy for the NGO 
and the campesinos alike by drawing attention precisely to the potentially very different moral commitments that peasants had when they engaged NGOs. ${ }^{25}$ The point is, however, that the moral terrain of campesinos was uneven and differentiated, sometimes converging with the values set out by NGOs but very often not.

At other times campesinos displayed a more conscious or articulated rejection of projects or their terms of implementation. Relations between NGOs and campesinos could become so strained that a community "drove out" an NGO by making its personnel feel unwelcome, or by being systematically obstructive. It seemed that all NGOs had their "problem community." One NGO in Paucartambo spoke of a community of difficult types who had rejected "technical assistance" on account of its insistence that women play a participatory role in the communal assembly. Another moved out of several communities of Urubamba when campesinos consistently defaulted on credit repayments. Campesinos' rejection of projects or of NGOs, however, would not necessarily reveal itself for some time. While promotores suspiciously believed that some peasants were apt to feign interest, even enthusiasm, reap the monetary or other incentives, and then demonstrate their "innate inconsistency" by "disappearing" (such is, perhaps, the origin of the proverbial denunciation of peasants within development circles: cuando dicen que sí, quieren decir que no: When peasants say "yes", they mean "no"), it must be remembered that any given project had to be implemented over time, sometimes years, and that promotores had to encounter shifting agendas and power constellations both within the communities and between themselves and communities. The conditions of NGO accountability to donors also varied, and this affected the expectations that promotores held of their subjects.

Projects were likely to have their "events" —occurrences that disrupted the normal unfolding of a project. Co-optation or hybridization of development materials with the local economy or within the spectrum of other social relations and ties persistently aggravated promotores, and threatened to unravel a particular project. At times, for instance, campesinos sold off the materials intended for projects. Thus in one community of Colquepata in Paucartambo Province, wire fencing for environmental conservation projects, erected with campesinos' labor, subsequently saw the wire removed and sold at the market. Anything from seed and inputs to sprinkler parts and cement were liable to disappear without a trace from their prescribed functions and locations. These materials were sometimes turned into gifts as part of the reciprocal exchanges among kin. ${ }^{26}$ Also, through bribery or differential power relations among campesinos, or between campesinos and small townships, the benefits of a given project could end up not in the hands of a targeted group but in those of another group. Exemplary among the complaints of one NGO was the water of a new water catchment that although destined for one community in Calca was "mysteriously" redirected into another. For the NGO, this event led to the dismissal 
of both communities, thereby concluding a fifteen-year history of "sabotaged" development initiatives.

While promotores tended to think in dualistic terms and the respective choices peasants had to make between development and underdevelopment, modern/market agriculture and traditional/subsistence agriculture, progress and impoverishment, peasants judged for themselves how useful and adaptable a particular technology or new agricultural practice was or would be. It is too narrow a view to assume that commitment to existing local agricultural modalities and corresponding forms of social organization were driven by ignorance, parochial reactivity, and the defence of tradition (Ploeg, 1993; Stern, 1987). Campesinos were constantly adjusting and adapting their ways of doing agriculture, usually in terms of what seemed to work for them. To promotores this may have looked like an adherence to traditional agriculture; for their part, campesinos were assessing and reassessing the value of existing practices in view of other options, whether the latter were pushed by promotores or were accessed independently. In consequence, campesinos were frequently departing from standards set by promotores. This could manifest itself during the course of a project's execution or once it was established. ${ }^{27} \mathrm{~A}$ case in point was an irrigation project in a community of Urubamba above the floor of the Sacred Valley. Here, a sprinkler system fed by underground pipes had been installed two years prior yet had remained, by NGO accounts, "unused." The NGO had tried to keep knowledge of the "failure" from the European donor, but it had finally been disclosed and the NGO was under pressure to justify the initial investment and redeem the system. Visiting the project again after a long absence, the technicians agreed the system was technically flawed: it would have to be reconfigured and the campesinos treated to rigorous training in sprinkler management. ${ }^{28}$ Yet my own inquiries with the campesinos revealed that the system had been used. It transpired that "unused" to the NGO had meant "badly under-utilized." One technician subsequently qualified this at some 20 percent of capacity, which, he claimed, was reflected in only a marginal and unsatisfactory increase in productive output. In contrast to the perspective of the NGO, it seemed that the campesinos had no parallel sense of "under-utilization." They had been using the system in certain circumstances, evidently, in conjunction with their existing practices-routinely criticized by NGOs for its degrading environmental effects—of irrigation by flooding.

Although I share the view of Gelles (2000) among others that there is a recognizably Andean set of ritualized agricultural practices embedded within social organization and a distinctly Andean worldview, much of these practices are hybridized such that the "internal" and the "external" have both come to conflate in the local. ${ }^{29}$ However, the point here is not to enter the debate about hybridization versus Andeanization, or the extent to which we can speak of a "traditional" local Andean knowledge at all. Rather, I am simply suggesting that at any given time in a 
given community, a certain knowledge configuration will exist and "other knowledge" will be external, unfamiliar.

Development, intent on bringing new knowledge and technologies to bear on peasant communities, needs to transform campesinos understandings of what they want in order to elicit favorable responses to projects. Innovation may or may not run against the grain of what they are already doing but may imply adapting present practices or a more far-reaching transformation, which may redefine the very meaning of what agriculture is and how it is inscribed politically and culturally into the everyday lives of campesinos. Either way, campesinos must be persuaded to desire particular outcomes.

\section{Persuasion, expertise and authority}

The NGOs' response toward what they understand as uncooperative behavior consists in reinventing a myriad of already entrenched stereotypical constructs of rural Andeans in terms of their backwardness, complacency, mentality, and so forth. These "defects" are associated with an overarching concept of "tradition" and have their historical roots in colonial and early republican discourses on Indians (Cadena, 2000; Harris, 1995). In face-to-face interaction, however, NGOs usually spare campesinos the kinds of characterizations that are made of them behind their backs. What is exposed when development workers meet peasants is rather an unrelenting effort to persuade them of their "real needs." On one occasion, a development worker by the name of María spoke with a campesino, Arturo, in a community near Cusco. María was proposing Arturo grow flowers for Cusco's burgeoning flower market. The dialogue may be read as an attempt by María to translate the needs and desires of Arturo.

María: Ahora con el riego podrás cultivar más. ¿Por qué no ponen flores?

Arturo: Sí, estoy hablando con mi esposa sobre esto, porque es un trabajo más suave.

Todavía no quiere, pero es cosa de hablar.

M: Las flores no necesitan tiempo ni mucha agua. Lo importante es dinero, o sea ganas bastante.

A: La semilla es lo que falta acá. Poca porción y llevan con plata.

M: Un espacio nomás necesitas. Busca una semilla mejorada, con colores para que te paguen más. Pero ¡Es negocio! ${ }^{30}$

María's attempt to persuade Arturo involved generating objects and incorporating them into a particular assemblage of meanings. Arturo's reluctance was expressed through his account of his wife's hesitation and his own retort that seed was lack- 
ing and expensive. In effect he ignored the attempted translations of María which were constituted by her rendition of his needs in the context of a distinctly developmentalist vision of what irrigation, flowers, money, time, and business mean, or should mean, for Arturo.

Despite the deployment of more "objective" discernments of what campesinos need and why, the emotional cadences of persuasion typically remain condescending. This is captured not only linguistically but also extra-linguistically in tone and the general disposition that promotores adopt, particularly but not only when they feel obstructed. The following dialogue between a promotor, Carlos, and a campesino from a small community near Calca concerned the weighing of produce in order to calculate one's economic gains or losses which is an important aspect of being a "producer" and marks one of the transitions as peasants move from "subsistence farming" to "market-oriented farming." ${ }^{1}$ Emilio, the comunero, was evidently familiar with the idea of weighing produce, although he did not do so himself.

Carlos: Emilio, ¿no pesas tu producto?

Emilio: No, no peso.

$\mathrm{C}$ (with disapproval): ¡A qué es eso! ${ }^{32}$

Subsequently, in the absence of Carlos, Emilio explained to me that he had never weighed his produce. He continued:

¿Pesar? No hay por qué. No me interesa cuánto estoy produciendo en maiz, trigo o haba. Tenemos que sacar nuestros costos, dice el Ingeniero, para saber si hemos ganado o no en esta campaña. Simplemente me pongo triste si sale mal la cosecha, feliz si es buena, pero saber qué son los costos y si he ganado ... ${ }^{33}$

The negative tone and disposition of promotores frequently extended to a dismissive attitude toward a campesino's defence of his own preferences. For this reason perhaps, if campesinos' preferred course of action differed from the expectation of promotores, the former rarely appeared to elaborate on their reasons or intentions. Campesinos in dialogue with promotores became (notoriously) vague about what they were doing. ${ }^{34}$ The underlying meaning of that vagueness may or may not have been lost on promotores, who, either way, continued to insist upon where the "real needs" of campesinos lay. This, after all, belonged to the vocation of being a development promotor and the voice of "expertise" that accompanied it. ${ }^{35} \mathrm{How}$, then, did this representation of real needs play out in practice? I proceed to exemplify this through an ethnographic account of power based on the constructed authority of "expert" knowledge vis-à-vis "inexpert," "lay" or "traditional” knowledge. 
A workshop on livestock management was on the agenda for a group of peasants from Llactapata in May 1998. Located within half an hour's drive from Cusco, Llactapata was a small comunidad campesina consisting of some thirty families. Like many campesinos in this area, most of Llactapata's peasants were Protestants whose menfolk in particular, after Quechua, spoke reasonable Spanish. At the markets and in other domains, these comuneros had many social and economic links to Cusco and some of their children were educated there. Agriculturally, they produced for themselves and sold or traded their surplus. In Llactapata, agriculture was not ritualized in the "Andean way," 36 yet it retained many features historically associated with Andean agricultural methods, for instance, the use of multiple ecological niches and rotational cropping on the communal lands at higher elevations (Morlon, 1992; Zimmerer, 1992). Of particular relevance here was the existing system of grazing livestock, which was strategically incorporated into the muyu or laymi pattern of bringing non-irrigated, high altitude rotative sectors into cultivation after a fallow period. This mode of agropastoral management ensured that fields lying fallow were regenerated while preventing damage to crops and soils. And under collective control, this organization also served to affirm the social cohesion of the collective (Zimmerer, 1992; Harris, 1995:368).

Over the past three decades, Llactapata had been involved in many agricultural development projects sponsored by state departments and NGOs. In particular, the community shared a dam, constructed in 1985 , with a neighboring community, which in conjunction with a sprinkler system afforded it a modest crop in the dry season for the low areas under cultivation. Subsequent developments had sought various ways of taking advantage of this infrastructure.

The current livestock project was yet another that would rely on the availability of dry season water to produce fodder for cattle. The workshop would teach peasants the science of feeding and fattening cows in order to produce more meat for the market and higher incomes for peasants. It aimed to promote an intensive system of livestock production over an extensive one. Campesinos customarily practiced what had come to be termed by extension workers an "extensive system," a notion that campesinos would have had no comprehension of without the cognitive labor of promotores. ${ }^{37}$ The NGO, which had recently employed a young veterinary scientist from Lima and another technician in animal husbandry, aimed to build a more intensive system, where cattle would spend more time in shelters. The course would instruct campesinos in the installation of shelters and special feeding troughs, and in looking after the cattle in confined conditions. Particular attention would be paid to animal hygiene, health, and to dietary components. Injectable solutions of vitamins, metabolic stimulants, anti-anaemic and recalcifying mineral compounds would assist animal health and reproduction. A correct balance of barley and alfalfa, dietary supplements, vaccinations and immunizations would 
enhance milk production and fatten the animals. Equations would set investment costs against productivity and potential gains. Other equations would compare optimum productive potential to present figures. The message: extensive methods were deficient; "we" would be able to do much better with a semi-intensive and, ultimately, an intensive system.

The workshop took place in the training room at the NGO head office in Cusco. The some twenty participants arrived (half of them late) and seated themselves around the tables that were organized in a U-shape, while Juana, the trainer, positioned herself at the front. On the blackboard, she wrote in Spanish, the second language of these Quechua-speakers: Extensiva ("extensive"); Intensiva ("intensive"); Semi-intensiva ("semi-intensive"). Juana introduced these as three different livestock production systems. She put a question to Serapio, who was distractedly chatting with his neighbor, seemingly as her ploy to capture his attention.

Juana: Serapio, ¿Su sistema es extensivo, intensivo, o semi-intensivo?

Serapio: Intensivo.

J: ¿Por qué?

S: Para que los animales no tengan hambre.

$\mathrm{J}$ (shaking her head and pointing to "extensive" on the board): ¡Esto es lo que practican Uds. sin saberlo! ${ }^{38}$

Juana proceeded to elaborate on more of the deficiencies of what "they don't know they do"-the extensive livestock production system-and explained that the object of the course was to achieve a transition, initially, to a semi-intensive system, namely, one that retained some aspects of the extensive system, while progressively incorporating intensive livestock methods.

A re-ordering of campesinos' understandings was taking place. They were learning to organize their knowledge of "animal husbandry" into three categories hitherto unknown to them, and to recognize the drawbacks of their present ways as they embraced new ways associated with agricultural development. In effect, their existing knowledge was being translated into the new terms espoused by the NGO, while the emergent categories were purified as objects of knowledge.

The translations that were being effected were embedded in and relied upon a certain "learning culture." In this learning culture, relatively little needed to be said about what peasants presently knew and did, and far greater weight was placed on what they did not know. Thus, the workshop was positioned around both a separation between knowers and not-knowers and two distinct hierarchical values about what was known. As trainer, Juana knew. The campesinos, in contrast, were undergoing a transition from not knowing to knowing. The tension between campesinos not knowing and knowing was continually mediated through language. They were 
expected, at one level, not to know. Juana indicated this when she said, No podemos meter todos los conocimientos en la cabeza en un día ... poco a poco ("We can't learn everything in one day ... one step at a time”). A second type of language was sensitive to peasants becoming knowers:

Juana: ¿Cómo se llama este sistema? Ma ... ma ...?

Campesinos (in chorus): Manejo!

J: Muy bien! 39

Finally, another language constituted peasants as should-be knowers. Juana asked the peasants why the intensive system would be better, to which she was met with silence. She delivered the correct answer intoned with impatience and displeasure: “Más carne! Chicos, ¿qué pasa? ¡Deben saber esto!” (More meat! Boys, what’s up? You should know that!).

As to why campesinos "should know that" was not questioned by NGOs or promotores. On the contrary, they were confident that the campesinos should learn about this new knowledge and their associated technologies and practices. To do so was to progress. To not do so was to be left behind in a modernizing world, to be left on the margins of the new global economy. In effect, the workshop articulated the needs of peasants, encouraging them to understanding their needs according to the new demands of the world around them, of which the market was a central component.

What peasants needed was now placed into opposition with what they "no longer needed" to know or practice. Inculcating new knowledge practices strategically problematized specific aspects of existing knowledge, in particular those aspects that came to be seen as "inadequate" and were to be amended by new knowledge. Thus the deficiencies of existing knowledge were discursively co-constituted by the innovations deemed to be superior. In the context of the workshop, the NGO was well-positioned to ignore the divergent desires and objectives of peasants and, instead, assumed a natural and non-negotiable alliance between desire and need. Such an alliance was bolstered by technical discourse which made a certain technological intervention appear "rational" in the pursuit of a given end. The technology itself became the stuff that made something possible; a something which was by all accounts constructed as naturally desirable: more meat, more income, greater access to services, in sum, "development." Technical discourse, then, served to naturalize and normalize desire: "aberrant desire" could only be the effect of a problem, an abnormality of agriculture, of being, and of the mind. 


\section{Discussion}

After the training course in intensive livestock management, the campesinos went home with free samples of vitamins and metabolic stimulants, admonished to continue building the corrugated iron lean-to shelters for their cattle. It was indeed illustrative that these shelters were being constructed inside the existing corral that butted on to the side of their huts: a corral that served as the "family enclosure" for the animals between pastoral excursions. ${ }^{40}$ In a very real sense, the new system was being placed over the existing one, covering it up, appropriating its space and reshaping a host of practices for the organization of a new sociotechnical assemblage linking campesino agriculture to both the disciplining and translating activities of the NGO and to the market.

But not only were the desires and livestock practices of the campesinos at issue here. Significantly, the NGO was not only busy trying to change aspects of livestock production. It also was wanting to establish and consolidate a network link between itself and the campesinos. It was in the interests of the NGO to enroll this group of comuneros in its project, for funding had been provided for it and would continue to flow only so long as this project and others like it could be represented as "successful." At stake was the ongoing viability of this particular NGO and the social and economic position of the promotores employed by it. The critical interests of the NGO itself were eclipsed by the constant repetition of a discourse that pronounced that development, ultimately, was enacted for its "beneficiaries," the campesinos.

As with any development project, multiple interests were at stake-those of campesinos, promotores, donors, and, although hidden in this account, those of research centers, providers of technical equipment, merchants and the "integrating national economy." Translation in the sense of Actor-Network Theory, amounted to the process of one group of promotores enrolling the interests of another by giving them a role and speaking on their behalf. In the above case, the promotores did so by articulating a division between "traditional" livestock practices and the new livestock management system to be implemented. They attached negative values to the latter and positive ones to the former in an effort to channel and translate the desires and needs of campesinos in the intended direction. At the same time, the materials critical for the new system were being brought into the community, making this much more than a rhetorical act of persuasion (cf Bardini, 1994). Finally, the very competence and status of campesinos vis-à-vis development, modernization, and progress were put on the line and measured. Although much of this was implicit, the participating campesinos had been told repeatedly that they had been chosen precisely because they were the most "progressive."

These strategies were interconnected with locations of expertise and nonexpertise which, in turn, were linked to "modern knowledge" and "traditional 
knowledge." The campesinos became nominally "in-expert" in their fields because a notion of "tradition" was discursively woven into the very practices development promised to redeem. Thus not only were locations of expertise relational, so too were ideas of what constituted "tradition" and "development." Development's knowledge played on a constant juxtaposition between its "progressive self" and that which was "traditional," and by implication, regressive, unproductive, and, at times, pathologically Andean. Despite the evidence that campesinos possessed real interpretative and practical skill as well as intimate knowledge of local agricultural conditions and crop varieties, etcetera (Ploeg, 1993; Wynne, 1996), this knowledge was often perceived to lack "expertise," "rationality," and "sanity" As Yúdice (1992:4) points out, modernity's "rational" self-image "blinds it to its own role as a source of pathology."

Would only a psychologically sick other deny such an opportunity to develop? As one frustrated technician phrased it while ignoring the irony of his assertion, los patas no hacen nada pues... no quieren desarrollarse porque son felizes con lo que tienen ("these chaps don't do anything ... they don't want to develop because they are happy with what they have). The sick peasant who suffered what was termed by one development worker as a kind of subdesarrollo mental ("mental underdevelopment"), was represented as a stereotypical adherent of "tradition." Another stereotype, at the other end of the spectrum, was the dynamic and progressive, market-oriented campesino. Reincarnations of either stereotype were symptomatic of the way peasant desire and need were constructed through translation. In addition, they were crucial to development's grass-roots strategy of problematizing existing agricultural practices as projects unfolded for the rural communities of Andean people. ${ }^{41}$

But these stereotypes also revealed the pressure of modernity in Andean spaces to transform "that which is." While "that which is" was forever changing according to a myriad of circumstances, it was purified as a category called "tradition," a timeless, static condition which, as an object, appeared as a synchronic hybrid of the internal and the internalized. What I show in this essay, however, is that synchronic hybrids are historical and ontological moments generated through processes of translation and purification (cf Verran, 2002). Yet at a deeper level, hybridity is diachronic in that it marks a passage between the internal, the external, and the internalized, and the constantly shifting relations between them.

Time would tell to what extent the campesinos would embrace the new assemblage of meanings and practices. Would they begin to disregard their former grazing practices, and how would this affect other aspects of their agriculture, which were woven into the existing pastoral system? Would they hybridize the "new" and the "old", injecting the stimulants into all the "wrong" places, re-roofing their padrino's (godfather) house with the iron intended for the lean-to, giving the vita- 
mins to their children or selling them in Cusco, and still, somehow, selling meat at the market? Would the NGO, a year after, be insisting that the campesinos keep their cows in the lean-to and not their chickens? Would the new system languish and come to nothing? Or would a single hybrid practice combining elements of "old and new" be forged while campesinos forgot what was, nominally, extensive and intensive livestock management? Whatever the outcome, the desire and enthusiasm of peasants, the articulation of need, the pathologization of "sick others," and the political relations within which they emerged, should not be taken as a given. Desire and rationality were under construction as vividly as the lean-to shelters themselves.

\section{Conclusion}

It requires no elaboration here that development is not, as one agronomist worded it, cuestión de tecnificar un poco lo que los campesinos ya hacen ("just a matter of'technifying' a little what the peasants already do"). As I have argued, such technical narratives dispel the contingencies and vicissitudes of human desire and recast it in the mold of universal needs. Universal needs are oddly incongruous with the types of divergences or "resistance" that ethnographers of development are constantly observing in the field. What, then, is development about as it is performed in this opprobrious "Third World" of rural, indigenous spaces? I have tried to show that development is about authoritatively translating practices into the life-world of its subjects-subjects who deliver development as well as those who receive it. "Successful" or not, the temporary and variable outcomes of development emerge as hybrids. ${ }^{42}$

The notion of hybridity allows us to exit the strictures of both essentialist interpretations of culture within a peoples/places model (Gupta and Ferguson, 1997) and discourse approaches to development, which tend to present development as a monolithic force emanating in the First World to dominate the Third World. ${ }^{43}$ As Grillo (1997) and Pigg (1997) have made clear, these frameworks reduce the agency of development subjects to one of compliance or resistance while simplifying the complexity of development as it both reshapes local environments and as local environments reshape it. But the notion of hybridity has emerged differently in ActorNetwork Theory than it has in postcolonialism and anthropology. Adopting the Actor-Network approach for the ethnographic study of postcolonial science and development implies a methodology of tracing the processes of translation and purification in the building of sociotechnical assemblages within development networks. ${ }^{44}$ Because these assemblages — or Latourian hybrids_-proliferate in intercultural arenas, these emerge as hybrids in the postcolonial sense. ${ }^{45}$

Bringing the Actor-Network approach to bear on the anthropology of develop- 
ment facilitates a methodology suited for analyzing the political processes of hybridization in diachronic terms, thereby enhancing descriptions of what often pass as synchronic hybrids with their attendant, yet "mixed," distinctions between Western and non-Western knowledge. Accordingly, hybridity comes to look less like a "postcolonial condition" than it does a temporal and diachronic process of relations_ at once strategic, material, discursive and technical ${ }^{46}$ — which are inherently asymmetrical and unequal. The respective contents of internal knowledge and external knowledge and practice at any given spatial and temporal juncture emerge contiguously within these relations. Similarly, the purified and generalized constructs of "Andean" and "Western" knowledge and culture, advanced by the development establishment and anthropologists alike, are also emergent within discourses of development and its counter-discourses (see Apffel-Marglin, 1994, 1998). The point, however, is not to argue on epistemic grounds about whether such "objects" really exist, but to treat them all as emergent phenomena, both "real" and constructed, within the very heterogeneous Andean landscape where the national and international "currency" of development loses its singular value (Yúdice, 1992:4). In this essay, then, I wanted to point to the social processes and translations that give objects of knowledge new meaning and make them useable (or dispensable) for the purpose of enrolment into a network. In particular, I was interested in pointing out that the multiple translations of desire and need in development contexts are part and parcel of the stuff that propels development forth, persuasively and authoritatively, into the lives of people who, in a very tangible sense, have known differently and done otherwise.

A translation analysis of desire allows us to see how development travels, how it moves between spaces, and intersects with local circumstances and local knowledge and technology. But do diachronic hybrids lead us back to notions of original culture, tradition, or of reified distinctions between the Andean and the Western, or, more generally, the West and the rest? Perhaps they could. But I am rather proposing that we maintain a distinction between the "internal" and the "external" as a divide that is not culturally or geographically inherent, but is in itself an effect of negotiations and power relations played out on the ambivalent terrain of postcolonial science and development.

When we consider Andean agricultural development touching on and reshaping the lives and practices of indigenous people, we might remind ourselves that emergent hybrids not only contain the synchronic character of "enthusiasm" but also the diachronic politics of convergence and divergence, of outside knowledge and inside knowledge, of power relations which attest less to a "postcolonial condition" and more to a "postcolonial process" of disciplining subjects. Although it is timely that we depart from our notions of purity (both ours and theirs) - in culture, identity, knowledge and technology—-we should not do so with such abandon 
that we begin to embrace a depoliticized and rampant mode of hybridization. The problem of this view of hybridization is that it ignores both the local and global politics of development and the very real divisions and power relations between groups who manifest strongly dualized locations of expertise and authority as power is split disproportionately between development knowledge and local knowledge. Hybridization, therefore, needs to be kept within the realm of power. Translation analysis as it has developed within the Actor-Network approach might make a substantial contribution to our knowledge of hybrids by providing important distinctions to the dangerous assumption that the spoils of modernity are simply wanted-or resisted-everywhere as a matter of course.

\section{Acknowledgement}

I would like to thank the editor, Jean Muteba Rahier, for his assistance in publishing this paper. I am also very grateful to the anonymous reviewers whose comments and ideas were extensively incorporated.

\section{Notes}

${ }^{1}$ People and place names have been changed to protect anonymity.

${ }^{2}$ In speaking of ambivalent subjects, one may recall Bhabha (1984), who argues that the identities of the colonized, who adopt the colonizers' language, are split or ambivalent. In this essay, I speak not of ambivalent identities, although this is arguable, but rather of what appears to be ambivalent attitudes toward development projects.

${ }^{3}$ The comunidad campesina is a legal entity, of which its members are comuneros. Most comuneros are campesinos inasmuch as they are farmers, but many campesinos are not comuneros if, for example, they are not members of a comunidad and lease land instead. As I am dealing only with campesinos who are also comuneros, I use the terms interchangeably.

${ }^{4}$ With the "permanent revolution of forms," Young (1995:25) refers to Bhabha's (1998) notion of hybridity as restless, interstitial, discontinuous and heterogeneous.

${ }^{5}$ Apffel-Marglin (1994:7) makes this important distinction.

${ }^{6}$ India's Green Revolution in wheat may be usefully compared and contrasted to Peru's Green Revolution in potato. See Shiva (1991) vis-à-vis Apffel-Marglin and Marglin (1990) and Apffel-Marglin $(1994,1998)$.

${ }^{7}$ Here, I am adapting Law's (1994) notions of a given social order and the processes of ordering.

${ }^{8}$ It is outside the scope of this essay to consider in any detail the locations of class, race and gender, suffice to say that the divide between "expert" and "lay" knowledge impinges profoundly on these locations both fortifying them while, curiously, allowing for their permeability. On the upward-mobility and the "hispanicization" of Andean peasants, which imply relocations of class, gender, racial and national 
identity, see Radcliffe $(1990,1996)$. More generally on class and indigenous people in Peru, see de la Cadena (2000).

${ }^{9}$ One of the important contributions of Actor-Network Theory has been to question the overriding emphasis on discourse which runs through many post-structuralist writings, and is evident in works on development such as those of Escobar $(1984,1995 \mathrm{a})$, and have strongly influenced the entire field of postcolonialism. Actor-Network Theory has looked at materials not as things constituted secondarily by discourse, but as co-constructed with discourse. See Law (1994), and Latour (1993).

${ }^{10}$ The Sociology of Scientific Knowledge (SSK), a sister discipline to Actor-Network Theory, has amply demonstrated that to bring science "on-side," or to capture science for oneself, is a major resource and that the real struggle takes place over what is to count as "scientific" either categorically, factually or experimentally. A number of studies of science in controversy bear this out: exemplary among them are Richards (1991) and Martin (1991). For a similar mode of argumentation in the context of Peru and postcolonial development, see Wynne (1996).

${ }^{11}$ Sensitive to the post-structuralist asymmetry which prioritizes language (mind) over matter (body), Actor-Network Theory reiterates the importance of the material dimension to translation and the agency of materials which, in Latour's phrasing, constitute "the non-Human" world, a world which is systematically and via the processes of purification removed from the "Human" world of politics, culture and agency. (See Latour 1993).

${ }^{12} \mathrm{On}$ the historical construction of underdeveloped highland spaces vis-à-vis coastal developed ones, and corresponding divisions between Creole and Indian peoples in Peru, see Shepherd (forthcoming).

${ }^{13}$ For general background on state and NGO roles, see chapters 3-5 in Bebbington and Thiele (1993).

${ }^{14}$ To raise the question of development in the rural Andes is to consider the integration of the peasant economy into the market. It is the market which determines value and it is the market where we need to generate conditions in order to attain greater remuneration for productive work. It is indispensable that we encroach on the sphere of commercialization to complement development projects carried out in the rural sector, which are based on, fundamentally, the introduction of technological change in order to augment production and productivity as a means of increasing the incomes and the quality of life of the population. (my translation)

${ }^{15}$ Following Harris (1995:368), I use the term “ethnic economy” to denote both subsistence and market strategies for social and agricultural reproduction.

${ }^{16}$ On the construction of universal needs, see Escobar (1995a, 1995b).

${ }^{17}$ It is pertinent to recognize that NGOs are now powerful political players in the postcolonial landscape and have in many places usurped the position of local municipalities and government ministries. On NGO roles generally in Latin American agriculture, see Bebbington and Thiele (1993). On the link between neoliberalism and structural adjustment on the one hand, and the proliferation of NGOs on the other, see Arellano-López and Petras (1994).

${ }^{18} \mathrm{Here}$, one should not presume that the success and failure of projects are self-evident; these interpretations are guided rather by the pragmatic choices of organizations. Shrum (2000) makes a similar observation for African NGOs.

${ }^{19}$ In the Andes, the number and turnover of NGOs is remarkable. An insight into this trade in the context of Africa can be gained by Shrum (2000), who describes the constant splitting of NGOs and their re-emergence through other NGO identities as a means of neutralizing existing political tensions and reactivating fresh techno-political agendas.

${ }^{20}$ See Grillo (1997) for his critique of the "development dictionary perspective," and Nanda (1999) on post-development.

${ }^{21}$ Escobar $(1995 a)$ and Apffel-Marglin $(1994,1998)$ are inclined to speak generally of resistance to 
development and of the spontaneous regeneration of autochthonous knowledge. Following Pigg (1997), I take no such general stance and focus rather on the local situation.

${ }^{22} \mathrm{At}$ times this appeared to be the case. However, while in this essay I am seeking to account for peasant agency, I do not wish to be over-speculative as to the motivations of peasants. Although promotores were constantly accounting for the motivations of their subjects, it would be superficial to take this "fieldwork information" as ethnographic interpretation.

${ }^{23}$ There are some excellent campesinos to whom we are going to give some $\$ 2,000$. But there are those that just turn up asking for an astronomical sum, and when you ask them what it's for they don't know what to say. Campesinos are always telling each other, "go in and just ask for money, just ask." (my translation)

${ }^{24}$ There are hens who eat their own eggs even if their beaks are cut off-those campesinos who have a barbaric capacity to get hold of information and go from one organization to the next to get money, and go to any length to do so. Credit isn't for them! (my translation)

${ }^{25}$ In development's language, this is seen to be part of the widespread problem of paternalismo or asistencialismo (paternalism).

${ }^{26}$ The obligations and reciprocities between kin, which are commonly articulated as an aspect of Andean culture, readily disrupt development's objectives since the latter propose that the market and market value should underlie exchange.

${ }^{27}$ Although it may be cynical to observe that NGOs may well not care what happens after a project is implemented providing donors can be kept satisfied and the continuing of funding assured, it is naive to assume that NGOs' main concern lies necessarily with the well-being of its target populations.

${ }^{28}$ As Pigg (1997) notes, to define problems as "technical" or "social" is strategic in itself, serving to apportion responsibility or blame in a desired way.

${ }^{29}$ See Gupta (1998).

${ }^{30}$ María: Now that we have installed the irrigation system, you can grow more. Why don't you grow flowers?

Arturo: Yes, I'm speaking with my wife about it, because it is a more gentle kind of work. She still doesn't want to, but its a matter of talking about it more

M: Flowers don't need much time or water. The important thing is money, in other words you'll make quite a lot

A: Seed is what is lacking here. You pay a lot for not much

M: All you need is a little extra space. Look for a hybrid seed that produces flowers with colors that pay well. Listen, it's business! (my translation)

${ }^{31}$ On the ethos, prevalent within agricultural economics, that the task of agricultural development in the Andes is to convert subsistence farmers into agricultural entrepreneurs, see Carlos Vera (1992).

${ }^{32}$ Carlos: Don't you weigh your produce.

Emilio: No, no I dont.

C: Where will that get you? (my translation)

${ }^{33}$ I have never weighed my produce. Theres no reason to. I'm not interested in how much maize, wheat or beans I am producing. They say I have to know, that I have to account for my costs so I know if I have made money or not for the season. But I simply get sad if the harvest is bad, happy if it's good, but as for knowing exactly what my expenses are and if I've profited ... (my translation)

${ }^{34}$ The interactive meaning of vagueness, silence, etcetera are necessarily speculative and difficult to substantiate empirically. Nevertheless, these forms recur as an inherent part of the interaction that ensues between members of different social groups in the Andes and is certainly reflective of the differential status and power of social groups.

${ }^{35} \mathrm{As}$ indicated, some NGO workers are drawn from the ranks of the peasantry, although these are 
trained on the job and not in universities as are the agronomists and other specialists who, for their part, receive wages four to fifty times greater than the employed campesinos. Those peasants who gain employment with NGOs feel themselves superior to their counterparts in the communities; nevertheless, it appears that they are more sensitive to the ways and means of their fellows than are the new graduates from Lima, many of whom are steeped in scientific and agricultural discourses but have very little appreciation of what Andean life is about, cannot speak Quechua and have little inclination to learn. These observations may be part of what Ploeg (1993:212) refers to as the "invisibility of peasants" as seen, or not seen, through the eyes of development experts. This invisibility or ignorance of both local culture and local knowledge is the principal theme in the Hobart (1993) collection.

${ }^{36}$ Probably due to the emergence of evangelical Protestantism, the Llactapateños have disassociated themselves from coca sharing and fertility rituals, and some claimed never to have heard of the Apus (mountain deities) or the Pachamama (Mother Earth). This, however, should be taken to mean the disappearance of underlying commitments to reciprocal exchange (ayni) or other collective organizational forms. See Allen (1988) on the particular significance of coca in Andean communities and Canessa (2000) on evangelismo.

${ }^{37}$ It is worth reiterating here that the nominally "extensive system" is not an ad hoc affair: campesinos guide the animals to where they know fodder of particular types will be found, and to spaces that are defined as communal grazing lands. Often, too, these lands are muyus en descanso (rotative sectors that are "resting" or in fallow). As Zimmerer (1992) observes, the grazing of animals on muyus is part of the land's regenerative cycle for it contributes to its re-fertilization. See Morlon (1992) for an overview of the Racionalidad Andina (Andean rationality) perspective that has come to exert a pervasive influence on Andean anthropology and history.

${ }^{38}$ Juana: Serapio, your system is extensive, semi-intensive, or intensive?

Serapio: Intensive

$\mathrm{J}$ : Why?

S: So that the animals don't go hungry.

$\mathrm{J}$ : This is what you people do without even knowing it! (my translation)

${ }^{39}$ Juana: What is this system called? Ma ... ma ...?

Campesinos: Management!

J: Very good! (my translation)

${ }^{40}$ I call this the "family enclosure" because, in the campesinos' world, the animals are treated as part of the family. How intensive livestock management will impact on this "ontological conviviality" between animals and humans is an important question, albeit one I do not deal with here. See Hirschkind (2000) for a useful account of that conviviality in the context of ethnoveterinary knowledge in Ecuador.

${ }^{41}$ On the subject of "other sick minds," we may recall Fanon (1967) who speaks of the "twisted psyches" of the colonized as an inevitable outcome of colonization. As I have intimated, development creates the stereotype of the ill subject as an integral part of its modus operandi. I do not, however, wish to point to sickness in any realist sense.

${ }^{42}$ To speak of hybrids may be to over-emphasize a total or stationary closure, denying process or, adapting Law (1994), opting for an anthropology of nouns over an anthropology of verbs. Hybrids rather, are happening, as in "hybridization": hybrids, therefore, are insubstantial.

${ }^{43}$ On development as discourse, see Cooper and Packard (1997), Crush (1995), Escobar (1984, 1995a, 1995b), Ferguson (1990), and Sachs (1992). For a critique of the "peoples/places model" in anthropological inquiry, see Gupta and Ferguson (1997).

${ }^{44}$ As a methodological maxim, this is put as "following the actors." Latour (1987) provides background.

${ }^{45}$ See Young (1995). 
${ }^{46}$ Actor-Network Theory stresses not only the heterogeneous nature of networks or assemblages, but also the dual political agency of all aspects, both human and non-human. (See Latour 1993).

\section{References Cited}

Allen, Catherine J.

1988 The Hold Life Has: Coca and Cultural Identity in an Andean Community. London, Macmillan.

Apffel-Marglin, Frédérique

1994 Development or decolonization in the Andes? Cultural Survival Quarterly (Winter):3-17.

1998 Introduction: Knowledge and Life Revisited. In The Spirit of Regeneration: Andean Culture Confronts Western Notions of Development. F. Apffel-Marglin, ed. Pp. 1-50. London: Zed Books.

Apffel-Marglin, F., and S. Marglin, eds.

1990 Dominating Knowledge: Development, Culture and Resistance. Oxford: Clarendon Press.

Arellano-López, Sonia, and James Petras

1994 La ambigua ayuda de las ONGs en Bolivia. Nueva Sociedad. 131:73-87.

Bardini, Thierry

1994 A Translation Analysis of the Green Revolution in Bali. Science, Technology, and Human Values 19(2):152-168.

Bebbington, Anthony, and Graham Thiele

1993 Non-governmental Organizations and the State in Latin America: Rethinking Bhabha, Homi K.

Roles in Sustainable Agricultural Development. London: Routledge.

1984 Of Mimicry and Man: the Ambivalence of Colonial Discourse. October 28:125-133.

1988 The Commitment to Theory. New Formations, 5:5-23.

de la Cadena, Marisol

2000 Indigenous Mestizos: The Politics of Race and Culture in Cusco, Peru, 1919-1991. Durham and London: Duke University Press.

Callon, Michel

1986 Some Elements of a Sociology of Translation: Domestication of the Scallops and the Fishermen of St. Brieuc's Bay. In Power, Action, and Belief: a New Sociology of Knowledge? Sociological Review Monograph 32. J. Law, ed. Pp. 196-233 London: Routledge and Keagan Paul.

Canessa, Andrew

2000 Contesting Hybridity: Evangelistas and Kataristas in Highland Bolivia. Journal of Latin American Studies 32:115-44.

Carlos Vera, José 
1992 La agricultura campesina y la agroexportación. Debate Agrario 13:245-261.

Cooper, Frederick, and Randall Packard, eds.

1997 International Development and the Social Sciences: Essays on the History and Politics of Knowledge. Berkeley, Los Angeles, London: University of California.

Crush, Jonathan, ed.

1995 Power of Development. London: Routledge.

Domingo, Luís M.

1995 Proyectos de Comercialización desde las ONGs. Cusco: COINCIDE. Coordinación Intercentros de Investigación, Desarrollo y Educación.

Escobar, Arturo

1984 Discourse and power in development: Michael Foucault and the relevance of his work to the Third World. Alternatives 10:377-400.

1995a Encountering Development: the Making and Unmaking of the Third World. Princeton: Princeton University Press.

1995b Imagining a post-development era. In Power of Development. J. Crush, ed. Pp. 212-228. London: Routledge.

Fanon, Franz

1967 Black Skin, White Masks. New York: Grove Press.

Ferguson, James

1990 The Anti-Politics Machine: Development, Depoliticization and Bureaucratic Power in the Third World. Cambridge: Cambridge University Press.

Gelles, Paul H.

2000 Water and Power in Highland Peru: The Cultural Politics of Irrigation and Development. New Brunswick, New Jersey, and London: Rutgers University Press.

Grillo, R. D.

1997 Discourses of Development: The View from Anthropology. In Discourses of Development: Anthropological Perspectives. R. D. Grillo and R. L. Stirrat, eds. Pp. 1-34. Oxford and New York: Berg.

Gupta, Akhil

1998 Postcolonial Developments: Agriculture in the Making of Modern India. Durham, London: Duke University Press.

Gupta, Akhil, and James Ferguson

1997 Culture, Power, Place: Ethnography at the End of an Era. In Culture, Power, Place: Explorations in Critical Anthropology. A. Gupta and J. Ferguson, eds. Pp. 1-29. Durham and London: Duke University Press.

Harris, Olivia

1995 Ethnic Identity and Market Relations: Indians and Mestizos in the Andes. Ethnicity, Markets, and Migration in the Andes: At the Crossroads of History and Anthropology. B. Larson and O. Harris, eds., with Enrique Tandeter. Pp. 350-390 Durham and London, Duke University Press.

Hirschkind, Lynn

2000 Sal/Manteca/Panela: Ethnoveterinary Practice in Highland Ecuador. American Anthropologist 102(2):290-302. 
Hobart, Mark, ed.

1993 An Anthropological Critique of Development: the growth of ignorance. London: Routledge.

Jennings, Bruce $\mathrm{H}$.

1988 Foundations of International Agricultural Research : Science and Politics in Mexican Agriculture. Boulder, Westview Press.

Larson, Brooke

1995 Andean Communities, Political Cultures, and Markets: The Changing Contours of a Field. In Ethnicity, Markets, and Migration in the Andes: At the Crossroads of History and Anthropology. B. Larson and O. Harris, eds. Pp. 5-53. Durham and London, Duke University Press.

Latour, Bruno

1987 Science in Action: How to follow Scientists and Engineers through Society. Milton Keynes: Open University Press.

1993 We Have Never Been Modern. Catherine Porter, trans. Cambridge, MA: Harvard University Press.

Law, John

1994 Organizing Modernity. Oxford, UK: Blackwell.

Martin, Brian

1991 Scientific Knowledge in Controversy: the social dynamics of the fluoridation debate. Albany N.Y.: State University of New York Press.

Mayer, E., and M. Glave

1992 Papas Regaladas y Papas Regalo: Rentabilidad, Costos e Inversión. Perú: el Problema Agrario en Debate. Sepia IV:87-120.

Morlon, Pierre, ed.

1992 Comprender la Agricultura Campesina en los Andes Centrales. Eduardo Rivera Martínez, trans. Paris, Cusco: IFEA, CBC.

Nanda, Meera

1999 Who Needs Post-Development? Discourses of Difference, Green Revolution and Agrarian Populism in India. Journal of Developing Societies: A forum for Developmental Issues in Developing and Developed Societies XV:5-31.

Pigg, Stacy Leigh

1997 Found in Most Traditional Societies: Traditional Medical Practitioners between Culture and Development. In International Development and the Social Sciences: Essays on the History and Politics of Knowledge. F. Cooper and R. Packard, eds. Pp. 259-29o. Berkeley, Los Angeles, London: University of California Press. Plaza, Orlando

1990 Desarrollo rural y cultura: ¿cambio y modernidad o modernidad sin cambio? In La Presencia del Cambio: Campesinado y Desarrollo Rural. H. Béjar, F. Eguren, O. Plaza and M. I. Remy, eds. Pp. 211-240. Lima, Centro de Estudios y Promoción del Desarrollo. DESCO.

van der Ploeg, Jan Douwe

1993 Potatoes and Knowledge. In An Anthroplogical Critique of Development: the 
Growth of Ignorance. Pp. 209-28. M. Hobart, ed. London: Routledge.

Radcliffe, Sarah A.

1990 Marking the boundaries between the community, the State and history in the Andes. Journal of Latin American Studies 22(3):575-594.

Radcliffe, Sarah, and Sallie Westwood

1996 Remaking the Nation: Place, Identity and Politics in Latin America. London: Routledge.

Richards, Evelleen.

1991 Vitamin C and Cancer: medicine or politics? Moundmills: Macmillan University Press.

Sachs, Wolfgang, ed.

1992 The Development Dictionary: A Guide to Knowledge as Power. London: Zed Books.

Shepherd, Chris. J.

(forthcoming) Imperial Science: The Rockefeller Foundation and Peruvian Agriculture, 1940-1960. Science as Culture: Special Edition; Postcolonial Technoscience.

Shiva, Vandana

1991 The Violence of the Green Revolution: Third World Agriculture, Ecology and Politics. London: Zed Books.

Shrum, Wesley

2000 Science and Story in Development: The Emergence of Non-Governmental Organizations in Agricultural Research. Social Studies of Science 30(1):95-124.

Stern, Steve. J.

1987 New approaches to the study of peasant rebellion and consciousness: implications of the Andean experience. In Resistance, Rebellion, and Consciousness in the Andean Peasant World, 18th to 2oth Centuries. S. J. Stern, ed. Pp. 3-25. Madison: University of Wisconsin Press.

Verran, Helen

2002 A Postcolonial Moment in Science Studies: Alternative Firing Regimes of Environmental Scientists and Aboriginal Landowners. Social Studies of Science $32(5-6): 729-762$.

Wynne, Brian

1996 May the Sheep Safely Graze? A Reflexive View of the Expert-Lay Divide. In Risk, Environment and Modernity: Towards a New Ecology. S. Lash, B. Szerszynski and B. Wynne, eds. Pp. 66-83. London, SAGE Publications:66-83.

Young, Robert J. C.

1995 Colonial Desire: Hybridity in Theory, Culture and Race. London and New York: Routledge.

Yúdice, George

1992 Postmodernity and Transnational Capitalism in Latin America. In On Edge, The Crisis of Contemporary Latin American Culture. George Yúdice, Jean Franco, and Juan Flores eds. Pp. 1-28. Minneapolis and London, University of Minnesota Press. 
Zimmerer, Karl S.

1992 Agricultura de Barbecho Sectorizada en las Alturas de Paucartambo: Luchas sobre la ecología del espacio productivo durante los siglos XVI y XX. Allpanchis 38:189-225. 